\title{
ANALISIS RETRIBUSI PASAR DAN RETRIBUSI PARKIR TERHADAP OPTIMALISASI PENDAPATAN ASLI DAERAH PEMERINTAH KABUPATEN BARITO TIMUR
}

\author{
Rosadiro Cahyono, Hendrawan \\ Sekolah Tinggi Ilmu Ekonomi Pancasetia Banjarmasin \\ Jl. Ahmad Yani Km. 5.5 Banjarmasin \\ hendra.anjank88@gmail.com
}

\begin{abstract}
This study aims to analyze market retribution and parking retribusion on the optimization of local revenue for the East District Barito Government. The data source of this research is the Regional Government Financial Report of East District Barito for 3 (three) years 2018 to 2020. The data analysis technique uses classical assumption test analysis and multiple linear regression analysis using SPSS version 24 for windows. The results showed that simultaneously the market retribution and parking retribution affect the local revenue of the East District Barito Government. Partially market retribution and parking retribusion have an effect on the local revenue of the East District Barito Government. Market retribusion have a dominant effect on local revenue in the East District Barito Government by $87,9 \%$.
\end{abstract}

Key words : Financial report, market retribusion, parking retribusion, local revenue and path analysis

\begin{abstract}
Abstrak: Penelitian ini bertujuan untuk menganalisis retribusi pasar dan retribusi pasar terhadap optimalisasi pendapatan asli daerah Pemerintah Kabupaten Barito Timur. Sumber data penelitian ini adalah Laporan Keuangan Pemerintah Daerah Kabupaten Barito Timur selama 3 (tiga) tahun 2018 sampai 2020. Teknik analisis data menggunakan analisis uji asumsi klasik dan analisis regresi linear berganda dengan menggunakan program SPSS versi 24 for windows. Hasil penelitian menunjukkan bahwa secara simultan retribusi pasar dan retribusi parkir berpengaruh terhadap pendapatan asli daerah Pemerintah Kabupaten Barito Timur. Secara parsial retribusi pasar dan retribusi parkir berpengaruh terhadap pendapatan asli daerah Pemerintah Kabupaten Barito Timur. Retribusi pasar berpengaruh dominan terhadap pendapatan asli daerah pada Pemerintah Kabupaten Barito Timur sebesar 87,9\%.
\end{abstract}

Kata kunci : Laporan Keuangan, retribusi pasar, retribusi parkir, pendapatan asli daerah, analisis regresi linier berganda. 


\section{Latar Belakang}

Otonomi daerah merupakan hak, wewenang, dan kewajiban daerah otonom untuk mengatur dan mengurus sendiri urusan pemerintah dan kepentingan masyarakat setempat sesuai dengan peraturan perundangundangan. Hal tersebut sesuai dengan ketentuan umum di UU Otonomi Daerah No. 32 Tahun 2004 tentang Pemerintah Daerah yang telah menggantikan UU No. 22 Tahun 1999. Pelaksanaan kebijakan pemerintah Indonesia tentang otonomi daerah, dimulai secara efektif pada tanggal 1 Januari 2001, merupakan kebijakan yang dipandang sangat demokratis dan memenuhi aspek desentralisasi yang sesungguhnya. Desentralisasi sendiri mempunyai tujuan untuk lebih meningkatkan kesejahteraan dan pelayanan kepada masyarakat, pengembangan kehidupan demokrasi, keadilan, pemerataan, dan pemeliharaan hubungan yang serasi antara pusat dan daerah dan antar daerah (Sidik et al, 2002 dalam Maemunah, 2006).

Otonomi daerah bertujuan menciptakan mobilisasi dukungan bagi kebijakan pembangunan nasional sampai ke pemerintah tingkat lokal, sehingga pembangunan yang dilakukan sesuai dengan kebutuhan dan aspirasi rakyat daerah. Pemberian otonomi daerah dilaksanakan dengan memperhatikan aspek demokrasi, keadilan, pemerataan serta potensi dan keanekaragaman daerah (Kameo, 2001). Dengan dikuranginya ketergantungan kepada pemerintah pusat maka Pendapatan Asli Daerah (PAD) seharusnya menjadi salah satu sumber keuangan terbesar dan menjadi tolok ukur terpenting bagi kemampuan daerah dalam menyelenggarakan dan mewujudkan kemandirian daerah.

Menurut Undang-Undang Nomor 33 tahun 2004 tentang Perimbangan Keuangan antara Pemerintah Pusat dan Daerah, timbul hak dan kewajiban daerah yang dapat dinilai dengan uang, sehingga perlu dikelola dalam pengelolaan keuangan daerah. Sumber-sumber Pendapatan Asli Daerah dirinci sebagai berikut: 1) hasil pajak daerah; 2) hasil retribusi daerah; 3) hasil perusahaan milik daerah dan hasil pengelolaan kekayaan daerah lainnya yang dipisahkan; dan 4) lain-lain pendapatan asli daerah yang sah. Salah satu komponen pokok dari Pendapatan Asli Daerah adalah retribusi daerah. Dengan demikian dalam rangka meningkatkan kemampuan Pendapatan Asli Daerah (PAD), salah satunya dapat ditempuh dengan jalan meningkatkan penerimaan daerah dari sektor retribusi daerah. Semakin besar penerimaan daerah dari sektor retribusi daerah, semakin besar pula kemungkinan daerah untuk meningkatkan tingkat kemandirian keuangan dalam pengelolaan pemerintahan dan pembangunan di daerah.

Sekalipun disadari tentang arti penting pendapatan asli daerah, termasuk retribusi daerah di dalamnya, namun sebagaimana dikemukakan sebelumnya, dalam kenyataannya kemampuan keuangan daerah dari sumber pendapatan asli daerah selama ini belum dapat diandalkan sebagai sumber pembiayaan penyelenggaraan pemerintahan dan pembangunan di daerah. Penelitian yang dilakukan Iskandar (dalam Kuncoro,1995: 9) menyimpulkan hasil bahwa dari periode tahun 1984/1985 sampai dengan tahun 1990/1991 rata-rata kemampuan Pendapatan Asli Daerah Kabupaten dan Kota dalam membiayai penyelenggaraan pemerintahan dan pembangunan hanya sekitar $15,4 \%$ dari keseluruhan biaya yang dibutuhkan atau pendapatan daerah.

Penerimaan Pendapatan Asli Daerah (PAD) merupakan sumber penerimaan yang signifikan bagi pembiayaan rutin dan pembangunan di suatu daerah otonom. Jumlah penerimaan komponen pajak daerah dan retribusi daerah sangat dipengaruhi oleh banyaknya jenis pajak daerah dan retribusi daerah yang diterapkan serta disesuaikan dengan peraturan yang berlaku yang terkait dengan penerimaan kedua komponen tersebut.

Retribusi daerah yang merupakan pembayaran atas jasa atau pemberian ijin khusus yang disediakan dan/atau diberikan oleh Pemda kepada pribadi/badan, diharapkan dapat mendukung sumber pembiayaan daerah dalam menyelenggarakan pembangunan daerah, sehingga akan meningkatkan dan memeratakan perekonomian serta kesejahteraan masyarakat di daerahnya. Beberapa faktor yang 
menyebabkan sektor retribusi daerah lebih potensial sebagai sumber keuangan daerah daripada sumber-sumber yang lainnya, antara lain:

1. Retribusi daerah dipungut atas balas jasa sehingga pembayarannya dapat dilakukan berulang kali. Siapa yang menikmati jasa yang disediakan oleh pemerintah daerah dapat dikenakan retribusi. Faktor perbedaan antara pungutan retribusi dengan sumbersumber pendapatan yang lain adalah ada tidaknya jasa yang disediakan oleh pemerintah daerah.

2. Pelaksanaan pemungutan retribusi dapat dilakukan di luar waktu yang telah ditentukan oleh petugas perundang-undangan selama pemerintah daerah dapat menyediakan jasa dengan persetujuan pemerintah pusat.

3. Sektor retribusi terkait erat oleh tingkat aktivitas sosial ekonomi masyarakat di suatu daerah. Artinya, semakin maju dan berkembang tingkat sosial ekonomi masyarakat, maka semakin besar potensi retribusi yang bisa dipungut.

Retribusi daerah pada dasarnya dikelola sendiri oleh setiap daerah, yaitu untuk pengelolaan retribusi daerah ini antara daerah yang satu dan daerah yang lain berbeda-beda. Berdasarkan Peraturan Pemerintah No. 66 Tahun 2001 tentang Retribusi Daerah, salah satu pungutan retribusi daerah adalah retribusi pasar dan retribusi parkir. Retribusi pasar dan retribusi parkir ini termasuk dalam retribusi jasa umum yang memberikan kontribusi yang cukup potensial terhadap peningkatan pembangunan dan kesejahteraan masyarakat. Untuk itu Pemerintah Daerah harus benarbenar menggunakan hasil retribusi pasar ini dengan sebaik-baiknya. Pajak parkir dan retribusi pasar merupakan bagian dari pajak daerah dan retribusi daerah, yang tercantum dalam UU No. 34 Tahun 2000, merupakan salah satu sumber pendapatan daerah guna membiayai penyelenggaraan pemerintah dan pembangunan.
Seiring laju pertumbuhan ekonomi dan pelaksanaan pembangunan daerah diperlukan sumber pembiayaan dalam melaksanakan kegiatan rumah-tangga daerah maka sumbersumber tersebut didapat dari Pendapatan Asli Daerah (PAD). Pemerintah daerah harus mengoptimalkan pendapatan-pendapatan daerah yang khususnya berasal dari pajak dan retribusi daerah, dimana pajak dan retribusi daerah merupakan salah satu sumber Anggaran Pendapatan Belanja Daerah (APBD).

Kabupaten Barito Timur merupakan daerah Pemerintahan yang sedang berbenah untuk meningkatkan angka penerimaan pajak dan retribusi daerahnya. Hal ini mutlak dilakukan mengingat masih banyaknya potensi-potensi sumber pajak dan retribusi daerah yang masih bisa ditingkatkan penerimaan pajak dan retribusinya. Diharapkan melalui proses pemungutan yang efektif, pemerintah Kabupaten Barito Timur dapat meningkatkan Pendapatan Asli Daerah sampai titik optimal.

Tabel 1.1 Laporan Realisasi Anggaran Pendapatan dan Belanja Daerah Kabupaten Barito Timur Tahun 2018 sampai 2020

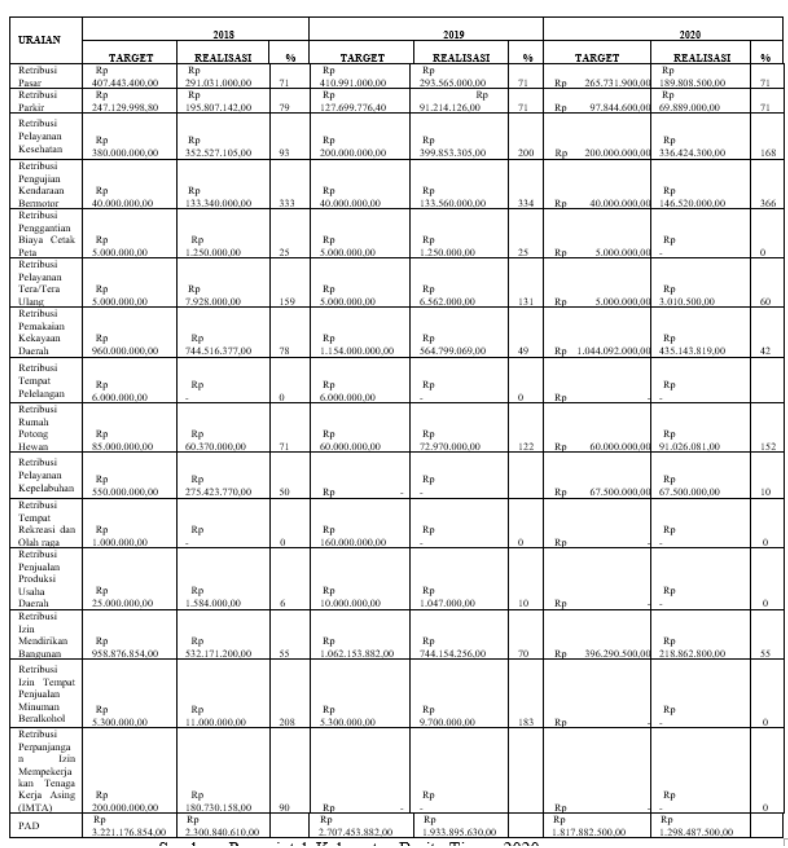

Sumber : Pemerintah Kabupaten Barito Timur, 2020

Dari Tabel 1.1 dapat dilihat bahwa retribusi pasar pada tahun 2018 mencapai Rp. 
291.031.,000,- dengan target sebesar Rp. 407.443.400,- atau dikatakan tercapai sebesar 71\%. Pada Tahun 2019 retribusi pasar mencapai Rp. 293.565.000,- yang berarti bahwa penerimaan retribusi pasar meningkat dari tahun sebelumnya dengan target pencapaian sebesar Rp. 410.991.000,- atau dikatakan tercapai sebesar $71 \%$ dari target. Pada Tahun 2020 penerimaan retribusi pasar mencapai Rp. 189.808.500,- yang berarti penerimaan retribusi pasar menurun dari tahun sebelumnya dengan target pencapaian sebesar Rp. 265.731.900,- atau dikatakan target tercapai sebesar $71 \%$. Penurunan penerimaan retribusi pasar di Kabupaten Barito Timur ini dipengaruhi oleh menurunnnya jumlah pedagang sebagai akibat dari dampak pandemi covid-19.

Berdasarkan data di lapangan, penerimaan retribusi parkir pada tahun 2018 mencapai Rp. 195.807.142,-, tahun 2019 mencapai Rp. 91.214.126,- dan tahun 2020 mencapai Rp. 69.889.000,-. Hasil penerimaan retribusi parkir ini masih belum mencapai target yang ditetapkan Pemerintah kabupaten Barito Timur, yaitu target pada tahun 2018 sebesar Rp. 274.129.998,80,- atau dikatakan tercapai sebesar $71 \%$. Target penerimaan retribusi parkir pada tahun 2019 adalah sebesar Rp. 127.699.776,40 ,- dengan pencapaian Rp. 91.214.126,- atau dikatakan tercapai sebesar $71 \%$, dan target pada tahun 2020 adalah sebesar Rp. 97.844.600,- dengan pencapaian sebesar Rp. 69.889.000,-atau dikatakan tercapai sebesar 43, 59\%. Pencapaian minimal target penerimaan Pendapatan Asli Daerah dari sektor penerimaan retribusi parkir yang harus dicapai di Pemerintah Kabupaten Barito Timur seharusnya minimal sudah tercapai sebesar hampir $80 \%$.

Pendapatan Asli Daerah pemerintah Kabupaten Barito Timur dari sektor retribusi diluar retribusi pasar dan retribusi parkir meliputi retribusi pelayanan kesehatan, retribusi pengujian kendaraan bermotor, retribusi penggantian biaya cetak peta, retribusi pelayanan tera/tera ulang, retribusi pemakaian kekayaan daerah, retribusi tempat pelelangan, retribusi rumah potong hewan, retribusi pelayanan ke pelabuhan, retribusi tempat rekreasi dan olah raga, retribusi penjualan produksi usaha daerah, retribusi izin mendirikan bangunan, retribusi izin tempat penjualan minuman beralkohol dan retribusi perpanjangan izin mempekerjakan Tenaga Kerja Asing (IMTA) dari tahun 2018 sampai dengan tahun 2020 bersifat fluktuatif.

Dalam kaitan ini perlu dikemukakan tentang strategis dan potensialnya retribusi pasar dan retribusi parkir pasar bagi peningkatan Pendapatan Asli Daerah Kabupaten Barito Timur. Dalam hal ini walaupun besarnya target pencapaian masih dibawah $80 \%$ sesuai target pencapaian minimal, namun menurut data tercatat bahwa retribusi parkir pasar selama tiga tahun berturut-turut (2018-2020) selalu mengalami kenaikan, sementara retribusi pasar yang lain walaupun memberikan kontribusi terbesar namun selama tiga tahun berturut-turut justru cenderung tetap atau cenderung mengalami penurunan. Ini menandakan betapa potensialnya retribusi parkir pasar bagi pendapatan asli daerah. Namun demikian, pengelolaan retribusi pasar selama ini dapat dikatakan belum optimal, sehingga dengan sendirinya juga mengakibatkan rendahnya efektifitas pendapatan asli daerah, terutama dari retribusi parkir pasar tersebut.

Pencapaian target retribusi parkir pasar menurut pengamatan awal penulis tidak terlepas dari belum optimalnya pelayanan yang dilakukan oleh Dinas Perdagangan dan Perindustrian Kabupaten Barito Timur. Berdasarkan data dan informasi dari Dinas Perdagangan dan Perindustrian Kabupaten Barito Timur bahwa alokasi dana untuk setiap tahun masih minim dibandingkan dengan kondisi pasar yang semakin tahun perlu ditingkatkan baik penampilan fisik maupun pelayanannya. Alokasi dana untuk setiap tahun anggaran hanya dipergunakan untuk biaya operasional. Alokasi dana untuk pasar yang minim secara operasional belum mampu meningkatkan kinerja pelayanan Dinas Perdagangan dan Perindustrian Kabupaten Barito Timur saat ini. Masih minimnya alokasi dana pemeliharaan sarana dan prasarana pasar tersebut turut mempengaruhi kesigapan para petugas dalam menanggapi keluhan para 
pedagang dan konsumen pasar terutama pada perbaikan sarana penunjang khususnya sarana parkir yang memadai.

Berdasarkan pada teori dan kondisi yang berkembang pada saat ini pada pertumbuhan suatu daerah maka perlu dilakukan penelitian empirik yang menganalisis lebih mendalam dalam menguji tentang retribusi pasar dan retribusi parkir terhadap optimalisasi pendapatan asli daerah Pemerintah Kabupaten Barito Timur selama 3 (tiga) tahun dari 2018 sampai dengan 2020. Penelitian ini didasarkan pada keingintahuan peneliti tentang sejauhmana pengaruh ketiga variabel independent tersebut terhadap pendapatan asli daerah Pemerintah Kabupaten Barito Timur.

Berdasarkan latar belakang masalah yang telah diuraikan, maka dapat dirumuskan masalah-masalah dalam penelitian ini sebagai berikut:

1. Apakah retribusi pasar dan retribusi parkir berpengaruh secara simultan berpengaruh terhadap Pendapatan Asli Daerah Kabupaten Barito Timur;

2. Apakah retribusi pasar berpengaruh secara parsial berpengaruh terhadap Pendapatan Asli Daerah Kabupaten Barito Timur;

3. Apakah retribusi parkir berpengaruh secara parsial berpengaruh terhadap Pendapatan Asli Daerah Kabupaten Barito Timur.

Berdasarkan pada rumusan masalah di atas. maka tujuan penelitian yang ingin dicapai adalah:

1. Untuk menganalisis pengaruh secara simultan retribusi pasar dan teribusi parkir terhadap Pendapatan Asli Daerah Kabupaten Barito Timur;

2. Untuk menganalisis pengaruh secara parsial retribusi pasar terhadap Pendapatan Asli Daerah Kabupaten Barito Timur;

3. Untuk menganalisis pengaruh secara parsial retribusi parkir terhadap
Pendapatan Asli Daerah Kabupaten Barito Timur.

\section{Studi Literatur}

1. Semdi J. E. Sopbaba, Sugeng Rusmiwari, Willy Tri Hardianto .2012. JISIP: Jurnal Ilmu Sosial dan Ilmu Politik ISSN. 20887469 Vol. 1, No. 2 (2012) dengan judul penelitian Implementasi Kebijakan Retribusi Parkir terhadap PAD. Hasil penelitian menujukkan bahwa pemberian otonomi kepada daerah bertujuan memberi kewenangan kepada daerah untuk mengatur dan mengurus rumah tangganya sendiri. Salah satu sumber penerimaan retribusi daerah yang cukup besar adalah retribusi parkir. Sektor ini merupakan salah satu sumber penerimaan yang penting karena selalu mengalami perkembangan seiring dengan berkembangnya suatu kawasan (kota), sehingga bila dikelola dengan baik dapat menunjang pendapatan asli daerah (PAD). Metode penelitian yang digunakan bersifat kualitatif. Pengambilan informan menggunakan teknik purposive sampling dan snowball sampling sedangkan teknik pengumpulan data melalui interview, observasi dan dokumentasi. Data dianalisis melalui tiga tahapan, yakni reduksi data, penyajian data dan penarikan kesimpulan. Hasil penelitian menunjukan bahwa pada tiga tahun terakhir (2009 S/D 2011) retribusi parkir memberikan kontribusi sebesar rata-rata 1,49\% terhadap PAD di Kota Batu tiap tahunnya. Hal ini menunjukan bahwa kontribusi retribusi parkir masih tergolong kecil. Selanjutnya pemungutan retribusi parkir di Kota Batu dilaksanakan melalui beberapa tahapan antara lain : a) Penetapan Objek Parkir; b) Pemungutan Retribusi Parkir dan c) Penagihan. Pemungutan retribusi parkir di Kota Batu dipengaruhi: 1) Rendahnya Kesadaran masyarakat; dan 2) Rendahnya Sistem Pengawasan.

2. Stephanny Inagama Timisela . 2013. Jurnal Kajian Ekonomi Dan Keuangan 
Daerah Vol. 2 No. 1 ISSN 2477-7838 dengan judul penelitian Analisis Penerimaan Retribusi Parkir Tepi Jalan Umum Di Kota Jayapura. Rumusan masalah dalam penelitian ini Pengelolaan retribusi parkir tepi jalan umum di Kota Jayapura, belum dilaksanakan secara efektif dalam rangka optimalisasi potensi Penerimaan Asli Daerah. Hal ini antara lain dapat ditemukan adanya kebocoran sekitar $59 \%$ pertahun. Dalam mengantisipasi persoalan kebocoran realisasi dan optimalisasi potensi Parkir Tepi Jalan Umum di Kota Jayapura, hal ini dapat dilakukan melalui strategi peningkatan maupun penataan Aspek Regulasi, Sumber Daya Manusia, Kesadaran Masyarakat, Kelembagaan, dan Sistem dan Prosedur.

3. Abdul Rajab. 2020. GROWTH: Jurnal Ilmiah Ekonomi Pembangunan p-ISSN: 2621-3842, e-ISSN: 2716-2443 Volume 1, No. 2, 2020. Dengan judul Penelitian Kontribusi Retribusi Pasar Terhadap Pendapatan Asli Daerah Di Kabupaten Mamuju. Penelitian menyatakan bahwa pada dasarnya belanja suatu daerah itu sangat tergantung dari pendapatan daerahnya itu sendiri. Pendapatan daerah sangat tergantung dari pajak dan retribus, salah satu pemasukan dari retribusi sendiri adalah retribusi pasar. olehnya itu, pemerintah harus mengoptimalkan pendapatan dari retribusi pasar. Penelitian ini bertujuan difokuskan untuk menganalisis sejauh mana Kontribusi Retribusi Pasar Terhadap Pendapatan Asli Daerah di Kabupaten Mamuju. Peneltian ini bertujuan untuk mengetahui peran dan perkembangan kontribusi retribusi pasar terhadap pendapatan asli daerah di Kabupaten Mamuju. Metode analisis yang digunakan pada penelitian ini ada analisis kontribusi. Berdasarkan analisis kontribusi yang dilakukan maka hasil yang diperoleh adalah kontribusi retribusi pasar terhadap Pendapatan Asli Daerah di Kabupaten Mamuju selama periode tahun 2014 sampai dengan tahun 2018 berkisar antara $1,52 \%$ sampai $1,1 \%$ dengan rata- rata kontribusi mencapai $1,29 \%$. Kontribusi retribusi pasar terhadap Pendapatan Asli Daerah terbesar terjadi pada tahun 2014 dengan kontribusi 1,52\% dan kontribusi terkecil terjadi pada tahun 2017 dengan kontribusi 1,08\%.

\section{Metode Penelitian}

Penelitian ini termasuk dalam penelitian metode kuantitatif untuk menjelaskan pengaruh hubungan antar variabel dengan menggunakan uji asumsi klasik dan analisis regresi, dalam hal ini adalah kondisi penerimaan pendapatan asli daerah di Kabupaten Barito Timur, strategi yang akan dibuat berdasarkan dari data yang diperoleh baik data primer maupun sekunder, seperti studi literatur, observasi dan interview., penelitian ini beranjak dari data deskriptif yang berhubungan dengan pokok bahasan yang kemudian dianalisis dengan menggunakan path analisis.

\section{Populasi dan Sampel}

Yang dimaksud populasi didalam penelitian ini merupakan wilayah generalisasi yang terdiri dari obyek/subyek yang memiliki kuantitas dan karakteristik tertentu yang ditetapkan oleh peneliti untuk dipelajari dan kemudian ditarik kesimpulannya, sedangkan menurut Arikunto populasi adalah keseluruhan objek penelitian. Populasi yang digunakan dalam penelitian ini adalah Laporan Penerimaan Retribusi Pasar, Laporan Penerimaan Retribusi Parkir dan Laporan Pendapatan Asli Daerah Pemerintah Kabupaten Barito Timur Anggaran Tahun 2018-2020.

Sampel adalah sebagian dari jumlah dan karakteristik yang dimiliki oleh populasi tersebut, ataupun bagian kecil dari anggota populasi yang diambil menurut prosedur tertentu sehingga dapat mewakili populasinya. Jika populasi besar, dan peneliti tidak mungkin mempelajari seluruh yang ada di populasi, hal seperti ini dikarenakan adanya keterbatasan dana atau biaya, tenaga dan waktu, maka oleh sebab itu peneliti dapat memakai sampel yang diambil dari populasi.

Sampel yang digunakan dalam penelitian ini adalah : 
1. Laporan Penerimaan Retribusi Pasar selama 3 (tiga) tahun, yaitu dari tahun 2018 sampai dengan 2020;

2. Laporan Penerimaan Retribusi Parkir selama 3 (tiga) tahun, yaitu dari tahun 2018 sampai dengan 2020;

3. Laporan Pendapatan Asli Daerah selama selama 3 (tiga) tahun, yaitu dari tahun 2018 sampai dengan 2020.

\section{Teknik Analisis Data}

Teknik analisis data yang dilakukan setelah semua data ini terkumpul adalah dengan menggunakan metode analisis deskriptif untuk menggambarkan hubungan antar variabel data yang diperoleh dengan landasan teori yang dipakai dalam penelitian ini dan dianalisis dengan menggunakan metode kuantitatif dengan menggunakan program SPSS versi 24.

\section{Uji Asumsi Klasik}

Sebelum dilakukan uji analisis berganda, terlebih dahulu dilakukan uji asumsi klasik. Kondisi tersebut akan terjadi apabila memenuhi asumsi klasik.

\subsection{Uji Normalitas}

Salah satu cara untuk menguji kenormalan adalah dengan menggunakan uji kolmogorov smirnov terhadap nilai standar residual hasil persamaan regresi. Bila uji one sample kolmogorov smirnov test lebih besar dari tingkat signifikan $(\alpha=0,05)$ maka distribusi data menyebar dengan normal dan sebaliknya.

\subsection{Uji Multikolinearitas}

Alat statistik yang sering digunakan unttuk menguji gangguan multikulinearitas salah satunya adalah dengan nilai toleransi atau nilai VIF (variance Inflation Factor) digunakan untuk mendeteksi adanya multikolinearitas. Batas Tolerance Value adalah $>0,10$ dan $\mathrm{VIF}<10$
(Suliyanto, 2011). Jika Tolerance value dibawah 0,1 atau Nilai VIF diatas 10 maka dapat dipastikan telah terjadi Multikolinearitas. Untuk itu ada alternatif cara untuk mengatasi masalah Multikolinearitas adalah sebagai berikut :

1. Mengganti atau mengeluarkan variabel yang mempunyai korelasi tinggi.

2. Menambah Jumlah Observasi

\subsection{Uji Heteroskedastisitas}

Dalam penelitian ini digunakan Gleiser untuk mendeteksi adanya heteroskedastisitas, dengan cara meregresikan nilai absolut residual terhadap variabel independent dengan persamaan regresi (Ghozhali, 2009).

\subsection{Uji Autokorelasi}

Uji autokorelasi digunakan untuk melihat apakah ada hubungan linear antara error serangkaian observasi yang diurutkan menurut waktu (data time series). Uji autokorelasi perlu dilakukan apabila data yang dianalisis merupakan data time series (Gujarati, 1993).

\subsection{Uji Linearitas}

Uji linearitas dipergunakan untuk melihat apakah model yang dibangun mempunyai hubungan linear atau tidak.Uji ini jarang digunakan pada berbagai penelitian, karena biasanya model dibentuk berdasarkan telaah teoritis bahwa hubungan antara variabel bebas dengan variabel terikatnya adalah linear. Hubungan antar variabel yang secara teori bukan merupakan hubungan linear sebenarnya sudah tidak dapat dianalisis dengan regresi linear, misalnya masalah elastisitas.

Jika ada hubungan antara dua variabel yang belum diketahui apakah linear atau tidak, uji linearitas tidak dapat digunakan untuk memberikan adjustment bahwa hubungan tersebut 
bersifat linear atau tidak. Uji linearitas digunakan untuk mengkonfirmasikan apakah sifat linear antara dua variabel yang diidentifikasikan secara teori sesuai atau tidak dengan hasil observasi yang ada. Uji linearitas dapat menggunakan uji DurbinWatson.

\section{Pengujian Hipotesis}

Analisis jalur (Path Analysis) adalah analisis untuk mengetahui besarnya sumbangan pengaruh setiap variabel $\mathrm{X}$ terhadap $\mathrm{Y}$ yang menggunakan regresi dengan variabel di bakukan (standardized). Dengan path analysis akan dilakukan estimasi pengaruh kausal antar variabel dan kedudukan masing-masing variabel dalam jalur. Signifikansi model tampak berdasarkan koefisien beta $(\beta)$ yang signifikan terhadap jalur.

Secara umum, analisis regresi pada dasar adalah studi mengenai ketergantungan variabel dependent (terikat) dengan satu atau lebih variabel independen (variabel penjelas/bebas), dengan tujuan untuk mengestimasi dan/atau memprediksi rata-rata populasi atau nilai rata-rata variabel dependen berdasarkan nilai variabel independen yang diketahui (Gujarati, 2003). Hasil analisis regresi adalah berupa koefisien untuk masing-masing variabel independen, koefisien ini diperoleh dengan cara memprediksi nilai variabel dependen dengan suatu persamaan. Koefisien regresi dihitung dengan dua tujuansekaligus : pertama, meminimumkan penyimpangan antara nilai actual dan nilai estimasi variabel dependen berdasarkan data yang ada (Tabachnick, 1996).

Secara statistic, setidaknya ini dapat diukur dari nilai koefisien determinasi, nilai statistik $\mathrm{F}$ dan nilai statistic t. Perhitungan statistic disebut signifikan secara statistic apabila nilai uji statistiknya berada dalam daerah kritis (daerah diman Ho ditolak). Selanjutnya disebut tidak signifikan bila nilai uji statistiknya berada dalam daerah dimana Ho diterima.

1. Koefisien Determinasi

Koefisien determinasi

(R2) adalah untuk mengukur sejauhmana kemampuan model dalam menerangkan variasi variabel dependen. Nilai koefisien determinasi adalah antara nol dan satu. Nilai R2 yang kecil berarti kemampuan variabel-variabel independen dalam menjelaskan variasi variabel dependen amat terbatas. Nilai yang mendekati satu berarti variabel-variabel independen memberikan hamper semua informasi yang dibutuhkan untuk memprediksi variabel-variabel dependen.

2. Uji Statistik F

Uji ini dilakukan untuk menguji pengaruh variabel bebas terhadap variabel terikat secara bersamaan. taraf signifikansi yang digunakan $(\square)$ sebesar $5 \%$. Sedangkan yang menjadi derajat kebebasan adalah $:(\mathrm{df})=(\mathrm{k}-1)(\mathrm{n}-\mathrm{k})$.

Dalam pengujian ini, FHitung dibandingkan dengan FTabel, apabila FHitung> FTabel maka hipotesis 1 diterima, yang berarti variabel bebasnya secara simultan mempunyai pengaruh secara nyata terhadap variabel terikat, dan sebaliknya jika FHitung< FTabel, maka hipotesis ditolak.

3. Uji Statistik t

Uji keberartian koefisien (bi) dilakukan dengan statistik t. Hal ini digunakan untuk menguji koefisien regresi secara parsial dari variabel independennya. Untuk menentukan apakah pengaruhnya signifikan atau tidak, melihat dari perbandingan nilai thitung dan ttabel. Jika 
thitung > ttabel maka Ho ditolak dan Ha diterima. Artinya secara parsial variabel independen $(\mathrm{X})$ berpengaruh signifikan terhadap variabel dependen $(\mathrm{Y})=$ hipotesis diterima. Jika thitung< ttabel maka Ho diterima dan $\mathrm{Ha}$ ditolak maka dikatakan tidak sigifikan. Artinya secara parsial variabel independen (X) berpengaruh tidak signifikan terhadap variabel dependen $(Y)$ $=$ hipotesis ditolak.

\section{Hasil Penelitian dan Pembahasan}

Tujuan penelitian adalah untuk menganalisa pengaruh retribusi pasar dan retribusi parkir terhadap pendapatan asli daerah Pemerintah Daerah kabupaten Barito Timur .

Hipotesa pertama menyatakan bahwa Retribusi Pasar dan Retribusi Parkir secara simultan berpengaruh signifikan terhadap Pendapatan Asli Daerah Pemerintah Kabupaten Barito Timur. Berdasarkan hasil analisis penelitian yang sudah dilaksanakan, dinyatakan bahwa retribusi pasar dan retribusi parkir secara simultan berpengaruh signifikan terhadap pendapatan asli daerah pemerintah daerah Kabupaten Barito Timur. Hal tersebut dibuktikan dengan hasil uji $\mathrm{F}$ diperoleh nilai sebesar 116,158 dengan nilai signifikan ( $\mathrm{p}$ value) sebesar 0,000 dimana p-value lebih kecil dari 0,05. Dari hasil pengujian koefisien jalur dari X ke Y secara statistik adalah bermakna (pvalue dibawah 0,05). Koefisien determinasi (Rsquare) sebesar 0,879 menunjukkan bahwa retribusi pasar dan retribusi parkir secara simultan terhadap pendapatan asli daerah pemerintah daerah Kabupaten Barito Timur sebesar 87,9 \%, sisanya dipengaruhi oleh variabel lain diluar variabel penelitian ini.

Pendapatan Asli Daerah (PAD) merupakan sumber pendapatan penting bagi sebuah daerah dalam memenuhi belanjanya. Pendapatan Asli Daerah ini sekaligus dapat menujukan tingkat kemandirian suatu daerah. Semakin banyak Pendapatan Asli Daerah yang didapat semakin memungkinkan daerah tersebut untuk memenuhi kebutuhan belanjanya sendiri tanpa harus tergantung pada
Pemerintah Pusat yang berarti ini menunjukan bahwa daerah tersebut telah mampu untuk mandiri, dan begitu juga sebaliknya. Karena dengan adanya peningkatan PAD diharapkan dapat meningkatkan investasi pendapatan asli daerah pemerintah daerah, sehingga pemerintah dapat memberikan kualitas pelayanan publik dengan baik (Isti, 2016).

Jika pemerintah daerah akan mengalokasikan anggaran pendapatan asli daerah maka harus disesuaikan dengan kebutuhan daerah tersebut dengan mempertimbangkan PAD yang diterima (Nuarisa, 2012). Hal ini menunjukkan bahwa semakin banyak PAD yang diterima oleh daerah maka semakin banyak pula daerah dapat mengalokasikan dana untuk anggaran pendapatan asli daerah daerah tersebut. Karena Pendapatan Asli Daerah (PAD) merupakan sumber utama pendapatan pemerintah yang berasal dari sumber-sumber dalam wilayah daerah itu sendiri. Meskipun pendapatan asli daerah jumlahnya sedikit tetapi pendapatan asli daerah sangat berpengaruh, tidak hanya untuk alokasi pendapatan asli daerah tetapi juga dapat digunakan untuk belanja operasional. Selain itu, semakin tinggi pendapatan asli daerah yang diterima mencerminkan kemandirian daerah, yang artinya daerah tersebut semakin tidak bergantung kepada Pemerintah Pusat. Maka dari itu, hendaknya Pemerintah Daerah lebih terpacu lagi untuk lebih memanfaatkan sumber daya daerah yang tersedia guna meningkatkan pendapatan asli daerah.

Hasil penelitian ini sejalan dengan hasil penelitian Suwarni (2009) yang menyatakan bahwa pendapatan asli daerah berpengaruh negatif terhadap pendapatan asli daerah studi empiris pada pemerintahan Kabupaten/Kota di Pulau Kalimantan, meskipun demikian hasil penelitian ini tidak sejalan dengan hasil penelitian Muhammad Edwin Kadafi (2013) yaitu pendapatan asli daerah berpengaruh positif dan signifikan terhadap pengalokasian anggaran pendapatan asli daerah Pemerintah Kota Bandung.

Hipotesa kedua menyatakan bahwa Retribusi Pasar secara parsial berpengaruh signifikan terhadap Pendapatan Asli Daerah Pemerintah Kabupaten Barito Timur. 
Berdasarkan hasil analisis yang telah dilakukan, dinyatakan bahwa retribusi pasar secara parsial berpengaruh positif dan signifikan terhadap pendapatan asli daerah pemerintah daerah Kabupaten Barito Timur. Dari hasil pengujian koefisien regresi dari X1 ke Y secara statistik adalah bermakna ( $p$-value dibawah 0,05 ) sehingga dapat dikatakan bahwa hipotesa pertama yang menyatakan bahwa retribusi pasar secara parsial berpengaruh signifikan terhadap pendapatan asli daerah Kabupaten Barito Timur adalah terbukti.

Artinya apabila terjadi peningkatan hasil retribusi pasar pada Pemerintah Kabupaten Barito Timur maka akan meningkatkan pendapatan asli daerah pada Pemerintah Kabupaten Barito Timur. Koefisien Regresi menunjukkan hubungan positf terhadap pendapatan asli daerah Pemerintah Kabupaten Barito Timur dengan nilai sebesar 4,601. Berarti peningkatan retribusi pasar satu satuan maka akan meningkatkan pendapatan asli daerah Pemerintah kabupaten Barito Timur sebesar 4,601 satuan ( asumsi cateris paribus).

Penelitian ini sejalan dengan penelitian I Ketut Suprapta Adi dalam judul Kontribusi Retribusi Pasar Dalam Peningkatan Pendapatan Asli Daerah Kabupaten Tabanan yang mengemukakan bahwa hubungan antara Retribusi Pasar dengan Pendapatan Asli Daerah Kabupaten Tabanan sudah berbanding lurus atau dengan kata lain antara retribusi pasar dengan Pendapatan Asli Daerah saling menunjang dimana retribusi pasar ini mempengaruhi Pendapatan Asli Daerah Kabupaten Tabanan.

Hipotesa ketiga menyatakan bahwa Retribusi Parkir secara parsial berpengaruh signifikan terhadap Pendapatan Asli Daerah Pemerintah Kabupaten Barito Timur. Berdasarkan hasil analisis yang telah dilakukan, dinyatakan bahwa retribusi parkir secara parsial berpengaruh positif dan signifikan terhadap pendapatan asli daerah pemerintah daerah Kabupaten Barito Timur. Dari hasil pengujian koefisien regresi dari $\mathrm{X} 2$ ke Y secara statistik adalah bermakna ( $p$-value dibawah 0,05 ) sehingga dapat dikatakan bahwa hipotesa kedua yang menyatakan bahwa retribusi parkir secara parsail berpengaruh signifikan terhadap pendapatan asli daerah Kabupaten Barito Timur adalah terbukti.

Artinya apabila terjadi peningkatan hasil retribusi parkir pada Pemerintah Kabupaten Barito Timur maka akan meningkatkan pendapatan asli daerah pada Pemerintah Kabupaten Barito Timur. Koefisien Regresi menunjukkan hubungan positf terhadap pendapatan asli daerah Pemerintah Kabupaten Barito Timur dengan Nilai sebesar 3,781 . Berarti peningkatan retribusi parkir satu satuan maka akan meningkatkan pendapatan asli daerah Pemerintah kabupaten Barito Timur sebesar 3,781 satuan ( asumsi cateris paribus).

Pendapat ini sejalan dengan penelitian yang dilakukan oleh Murlan Suyanto, 2010 yang berjudul Pengaruh Retribusi Parkir Terhadap Pendapatan Asli Daerah Kabupaten Sidoarjo. Penelitian ini menyatakan bahwa adanya pengaruh retribusi parkir terhadap Pendapatan asli Daerah di Kabupaten Sidoarjo.

\section{Kesimpulan}

Berdasarkan hasil penelitian dan pembahasan, maka didapatkan beberapa kesimpulan sebagai berikut:

1. Retribusi pasar dan retribusi parkir secara simultan berpengaruh signifikan terhadap pendapatan asli daerah Kabupaten Barito Timur.

2. Retribusi pasar secara parsial berpengaruh signifikan terhadap pendapatan asli daerah Kabupaten Barito Timur.

3. Retribusi parkir secara parsial berpengaruh signifikan terhadap pendapatan asli daerah Kabupaten Barito Timur.

\section{Daftar Pustaka}

Abdul Rajab. 2020. Kontribusi Retribusi Pasar Terhadap Pendapatan Asli Daerah Di Kabupaten Mamuju. GROWTH: Jurnal Ilmiah Ekonomi Pembangunan p-ISSN: 2621-3842, e-ISSN: 2716-2443 Volume 1, No. 2, 2020. 
Gujarati, Damodar.1993.Ekonometrika Dasar, cetakan ketiga, Jakarta; Erlangga.

Gujarati, Damodar.2003 .Ekonometrika Dasar, cetakan keempat, Jakarta; Erlangga.

I Ketut Suprapta Adi. 1998. Kontribusi Retribusi Pasar Dalam Peningkatan Pendapatan Asli Daerah Kabupaten Tabanan. Bagian Hukum Administrasi Negara Fakultas Hukum Universitas Udayana.

http://download.garuda.ristekdikti.go.i d/article.php Diakses tanggal 2 Februari 2021.

Kameo, Daniel and Simon Malo Kii, "Regional Autonomy and its Implications on Regions" (Otonomi dan Kesiapan Daerah), NTT Express, 19 Mei 2001.

Kuncoro, Mudrajad. 1995. Ekonomi Pembangunan Teori, Masalah dan Kebijakan, Yogyakarta: UPP-AMP YKPN.

Muhammad Edwin Kadafi. (2013). Pengaruh Pendapatan Asli Daerah dan Dana Perimbangan terhadap Belanja Modal. Skripsi. Universitas Widyatama

Murlan Suyanto, 2010. Pengaruh Retribusi Parkir Terhadap Pendapatan Asli Daerah Kabupaten Sidoarjo. Diakses 23 januari 2021.

Mutiara Maimunah. 2006. Flypaper Effect pada Dana Alokasi Umum (DAU) dan Pendapatan Asli Daerah (PAD) terhadap Belanja Daerah pada Kabupaten/Kota di Pulau Sumatera, Simposium Nasional Akuntansi IX Padang 23-26 Agustus 2006.

Nuarisa Ardhian. 2013. Pengaruh PAD, DAU, Dan DAK Terhadap Pengalokasian
Anggaran Belanja Modal. Accounting Analysis Journal AAJ 2 (1) (2013) : ISSN 2252-6765.

Permatasari Isti. 2016. Pengaruh Pendapatan Daerah Terhadap Belanja Modal Pada Kabupaten/Kota Di Jawa Timur. Jurnal Ilmu dan Riset Akuntansi : Volume 5, Nomor 1, Januari 2016 : ISSN : 24600585 .

Semdi J. E. Sopbaba, Sugeng Rusmiwari, Willy Tri Hardianto .2012. Implementasi Kebijakan Retribusi Parkir terhadap $P A D$. JISIP: Jurnal Ilmu Sosial dan Ilmu Politik ISSN. 2088-7469 Vol. 1, No. 2 (2012).

Stephanny Inagama Timisela . 2013. Analisis Penerimaan Retribusi Parkir Tepi Jalan Umum Di Kota Jayapura. Jurnal Kajian Ekonomi Dan Keuangan Daerah Vol. 2 No. 1 ISSN 2477-7838.

Suwarni, Sri. 2009. "Pengaruh Pendapatan Asli Daerah (PAD), LainlainPendapatan Yang Sah (LPS), Dana Alokasi Umum (DAU) DanDana Bagi Hasil (DBH) Terhadap Pengalokasian Anggaran BelanjaModal Pemerintah Daerah (Studi Empiris Pada PemerintahKabupaten/Kota Di Pulau Kalimantan)." Universitas Sebelas Maret Surakarta.

Suliyanto. 2011. "Ekonometrika Terapan: Teori Dan Aplikasi Dengan SPSS". Edisi 1. Yogyakarta: ANDI Yogyakarta.

Tabachnick B.G. and Fidel, L.S., 1996, "Using Multivariate Statistics", Third Edition, Harper Collins College Publisher, New York. 